\title{
Soul and body: Transcending the dialectical intellectual legacy of the West with an integral biblical view?
}

\author{
Author: \\ Danie Strauss ${ }^{1}$ \\ Affiliation: \\ ${ }^{1}$ School of Philosophy, \\ North-West University, \\ Potchefstroom Campus, \\ South Africa \\ Correspondence to: \\ Danie Strauss \\ Email: \\ dfms@cknet.co.za \\ Postal address: \\ 3 Captain Goodman Street, \\ Danhof 9310, South Africa \\ Dates: \\ Received: 03 Mar. 2014 \\ Accepted: 17 June 2014 \\ Published: 19 Dec. 2014 \\ How to cite this article: \\ Strauss, D., 2014, \\ 'Soul and body: Transcending \\ the dialectical intellectual \\ legacy of the West with an \\ integral biblical view?' In die \\ Skriflig 48(1), Art. \#1815, \\ 12 pages. http://dx.doi. \\ org/10.4102/ids.v48i1.1815 \\ Note: \\ Paper presented at \\ 'The Soul Conference,' \\ Oxford, 28 June - 01 July \\ 2013. This work is based \\ upon research supported \\ by the National Research \\ Foundation. \\ Copyright: \\ (C) 2014. The Authors \\ Licensee: AOSIS \\ OpenJournals. This \\ work is licensed under \\ the Creative Commons \\ Attribution License.
}

Read online:

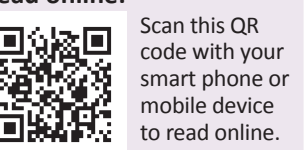

Greek philosophy informed the Medieval dualistic understanding of 'body' and 'soul', which continued to influence modern Humanism and Christian views during and after the Middle Ages. These fluctuating conceptions express the directing role of dialectical basic motives. It was mainly the Greek motive of matter and form which directed the thought of Plato and Aristotle, resulting in a dualistic view of the relationship between a so-called material body and rational soul. At the Council of Vienne (1312), the Aristotelian-Thomistic doctrine of the soul as the substantial form of the body was adopted. Within Protestant circles, the 'two-substances' view caused a distinction between a (temporal) material body and an (eternal) rational soul (see article 7 of the Swiss Confessio Helvetica Posterior and the Westminster Confession Chapter 4, paragraph 2). Dooyeweerd shows how modern philosophy has received its deepest motivation from the dialectical motive of nature and freedom, which informed the development from Descartes up to Gould and Jaspers. Finally, in the last sections, the main contours of a biblically informed view are articulated with reference to the centrality of the human I-ness, to the theory of enkaptic interlacements and to the problem of supra-temporality.

Siel en liggaam: Is dit moontlik om die dialektiese intellektuele erfenis van die Weste vanuit ' $n$ integrale bybelse siening te bowe te kom? Die Griekse filosofie vorm die agtergrond van die Middeleeuse dualistiese verstaan van 'liggaam' en 'siel' wat op sy beurt die moderne Humanisme en latere Christelike opvattinge beïnvloed het - almal in die greep van dialektiese grondmotiewe. Dit was hoofsaaklik die Griekse basiese vorm-materie-motief wat die dualistiese siening van 'n materie-liggaam en 'n redelike siel tot gevolg gehad het, soos dit in die denke van Plato en Aristoteles beslag gekry het. By die Konsilie van Wenen (1312) is die Aristotelies-Thomistiese leerstuk van die siel as substansiële vorm van die liggaam aanvaar. In Protestantse kringe het die 'twee substansies'-siening tot die onderskeiding tussen 'n (tydelike) materie-liggaam en 'n (ewige) redelike siel (vgl. artikel 7 van die Switserse Confessio Helvetica Posterior en die Westminster Confession Hoofstuk 4, paragraaf 2) aanleiding gegee. Dooyeweerd toon aan hoedanig die moderne filosofie sy diepste motivering vanuit die dialektiese grondmotief van natuur en vryheid ontvang, wat rigting sou gee aan die dialektiese ontwikkeling vanaf Descartes tot en met Gould en Jaspers. Aan die einde word die hoof-kontoere van 'n bybels-geïnspireerde siening geartikuleer, met verwysing na die sentrale posisie van die menslike selfheid, na die teorie van enkaptiese struktuurvervlegting en na die probleem van bo-tydelikheid.

\section{The dialectical split between body and soul: Its genesis in Greek culture}

Since its inception, Greek philosophy has struggled with the dialectical tension between the transitional world of becoming and the urge towards incorruptibility. Sometimes, other opposites, such as the limitless and the limited, the constant and the changeful, matter and form, are employed. What is special about this kind of dialectic is that the two poles both threaten and presuppose each other. Within the development of Greek culture, this split eventually resulted in the view that the human being is constituted by a rational soul and a material body. Thompson (2012:14) provides a clear account of the relationship between body, mind and soul in the thought of Plato and Aristotle.

\section{Plato}

In the context of the fear for death, the discussion leader in Plato's dialogue Phaedo (1966) proposes to obtain an answer to the question: 'For what sort of thing should we fear this fate, and for what should we not?' (Plato 1966, 77b). In search for an answer to this question, Plato 
relates 'what is always constant and invariable' to what is 'incomposite' and 'what is inconstant and variable' to what is 'composite'. What Plato has in mind is the status of his transcendent ontic forms (eidè). Plato distinguishes between the visible and invisible in terms of the invariable and what is never the same: 'So you think that we should assume two classes of things, one visible and the other invisible?', followed by specifying the question: 'The invisible being invariable, and the visible never being the same?' (Plato 1966, $77 b)$. Plato then claims that the 'body would have the closer resemblance and relation' with the visible whilst the 'soul is more like the invisible' (Plato 1966, 79c ff.). Therefore, in this dialogue, Plato argues that rational thinking is directed at what is invisible and constant. The visible and changeable, by contrast, can only be observed through the senses. He further explains this split by referring to an absolute reality which remains 'always constant and invariable' and then asks: 'Does absolute equality or beauty or any other independent entity which really exists ever admit change of any kind?' (Plato 1966, 77b). The alternative contemplated here is captured in the question: Does '... each one of these uniform and independent entities remain always constant and invariable, never admitting any alteration in any respect or in any sense?' (Plato 1966, 78d).

The explanation emerging from the on-going conversation anticipates the problem of positivism, which wants to restrict science to 'sense data', but then fails to account for the status of the terms employed in describing what has been observed by the senses. Plato distinguishes sensory objects from those entities that are constant: 'And these concrete objects you can touch and see and perceive by your other senses, but those constant entities you cannot possibly apprehend except by thinking; they are invisible to our sight' (Plato 1966, 78e).

In light of these views, it is not surprising that Plato (1966) repeatedly relates the distinction between soul and body to the distinction between what is constant and what is variable:

The soul is most like that which is divine, immortal, intelligible, uniform, indissoluble, and ever self-consistent and invariable, whereas body is most like that which is human, mortal, multiform, unintelligible, dissoluble, and never self-consistent (80b, p. 132).

Aristotle transforms the theory of ideas of Plato, and in doing this he continues to provide his own dynamic to the development of the Western intellectual legacy. Ernst Fischer (1996) remarks:

First Aristotle is translated, then he is ordered, subsequently he is subjected to commentaries, later on he is interpreted, soon he is criticised, sooner or later he is refuted, sometimes he is despised, and so it always proceeds until our contemporary situation, which is still strongly involved with Aristotle. (p. 15) ${ }^{1}$

1.Erst übersetzte man ihn, dann ordnete man ihn, anschließend kommentierte man ihn, später interpretierte man ihn, bald kritisierte man ihn, irgendwann wider man ihn, später interpretierte man ihn, bald kritisierte man ihn, irgendwann widerlegt man ihn, ab und zu verachtete man ihn, und so geht das immer weiter bis in unsere Gegenwart hinein, die immer noch stark mit Aristoteles beschäftigt ist und nach wie vor durch den selbst Unbewegten in Bewegung gehalten wird.'

\section{Aristotle}

Aristotle commences with a primary substance as signifying unit, designating 'that which is individual' (Aristotle 2001:8, Categ. 1b.5-6) However, he immediately introduces a 'secondary substance', which 'is not an individual, but a class with a certain qualification, since words like "man" and "animal" are "predicable of more than one subject"' (Aristotle 2001:12, Categ. 3b.10-18). Hartman discerns a close connection between concepts and universality in Aristotle's thought, although initially it was not asserted. To this, he (Hartman 1977) adds the remark that knowledge of a particular involves universals:

Aristotle does not say at first, as one might wish him to say, that even true belief presupposes a facility with concepts and therefore universals; but he does not shrink from the conclusion that knowledge of a particular (or, as he sometimes seems to mean, of a matter of fact concerning a particular) involves universals. (p. 21)

Whereas Plato's ideas do not depend upon their participants for their existence, Aristotle's '... universals do depend on their instances' (Hartman 1977:22). For this reason, what is recognised as particular still has to be of a 'certain sort': 'if it is entirely unique, nothing can be known about it' (Hartman 1977:25).

Having started with his (purely individual) primary substance, Aristotle knows he has to introduce something universal in order to secure the knowability of a substance. At the same time, Aristotle (2001: Metaphysics (Metaph.) 1087a.10-15) realises that there are serious problems involved in relating what is individual to universality and to knowledge:

The statement that all knowledge is universal, so that the principles of things must also be universal and not separate [individual] substances, presents indeed, of all the points we have mentioned, the greatest difficulty, but yet the statement is in a sense true, although in a sense it is not. (p. 911)

In line with this view, Aristotle, also considers the primary substance to be unknowable, because knowledge is only possible of the universal essence of things, which, as we noted above, is designated by Aristotle as the secondary substance, the to ti èn einai (cf. Aristotle 2001:556, 558, De Anima (DA) 412b.16; cf. 414a.9-11).

For Aristotle, true knowledge is therefore ultimately knowledge of the general form. In the third chapter of the seventh book of his Metaphysics, Aristotle articulates the negative implications of his stance by subtracting all positive determinations of being, thus rendering matter as such unknowable. Not only does he deny all positive determinations of being in respect of matter, for even negating them does not hold for matter (Aristotle 2001: Metaph. 1029a.24-25).

The absolute formless matter functions as the limit point of all negative designations. We are therefore here justified to 
discern a true via negativa in the conception of Aristotle. In his extensive work on matter in Aristotle's thought, Heinz Happ goes beyond the prote hule [primary matter] to what he considers to be Aristotle's highest matter principle, 'matter as such': 'The distinction between prima materia and "Hule-Prinzip" is nowhere explicitly made by Aristotle, and yet it follows necessarily from his argumentations' (Happ 1971:696-697). It may appear as if Happ reaches this conclusion by acknowledging both the positive and negative designations of matter. Since the designation primary matter still contains a positive affirmation (primary), Happ plays it off against Aristotle's negative approach. On the basis of this ambiguity, he then concludes to the highest matter principle of Aristotle. Of course, Happ does not realise that, for Aristotle, it is one and the same matter, which allows for approximating positive knowledge. However, negating conceptual determinations causes matter as such to escape from being conceived.

Moreover, matter as such finds its counterpart in its dialectical opposite, pure, actual form. Pötscher formulates it precisely when he explains that Aristotle understands his god in such extreme terms that it 'at once appears in pure dialectics as opposite, as the negation of what is material' (see Pötscher 1970:51). Ter Horst (2008) captures this ultimate dualism as follows:

For Aristotle matter is an eternal principle of movement and change, and of an unlimited transition of the one into the other; the form is likewise an eternal principle of enduring being, and of limitation to generic determination. (p. 28)

Verdenius and Waszink (1968:57) note that the principle of dūnamis and energeia rests on prote hule [primary matter] as a more fundamental principle - the 'ultimate substratum of all transformation' which 'never exists except qua determined by some form'.

Potency and act, instantiated as matter and form, are eternal, supra-temporal and non-generated principles of whatever there may be. Yet, these principles must be mutually related, although there is no theological necessity to reduce the one principle to the other, since the god of Aristotle, who is equated with the pure act, is no creator and therefore not the absolute origin of what is. ${ }^{2}$

Of particular importance in this regard is the fact that the Aristotelian conception of the relationship between the universal essence (universal substantial form = secondary substance) eventually turns out to be the starting point of the medieval (Thomistic, in particular) understanding of the relationship between the (material) body and the (rational) soul. According to Aristotle, substance could be understood in two senses: as the ultimate substratum, persisting through all changes, and as the form furnishing a 'this' with its distinct

\footnotetext{
2.'Potentie en akt, geinstantieerd als materie en vorm, zijn eeuwige, boventijdelijke en ongeworden beginselen van al het zijnde. Deze beginselen moeten wel op elkar worden betrokken, doch er bestaat geen theologische noodzaak het ene beginsel oorzakelijk tot het andere te herleiden. De God van Aristoteles, die met de zuivere oorzakelijk tot het andere te herleiden. De God van Aristoteles, die met de zuivere
akt wordt gelijkgesteld, is geen Schepper, en dus geen absolute oorsprong van het akt wordt gelijkgesteld, is geen
zijnde' (Ter Horst 2008:29).
}

meaning. Hartman (1977:29) explains: 'Matter is the subject of predication; form is what makes a substance what it is, and is therefore at least a necessary condition of the substance.'

Aristotle combines the relationship between matter and form with the difference between potentiality and actuality. He (Aristotle 2001:DA 412a.10-23) states categorically:

Now matter is potentiality, form actuality; ... the body cannot be soul; ... Hence the soul must be a substance in the sense of the form of a natural body having life potentially within it. But substance is actuality, and thus soul is the actuality of the body. (p. 555)

Therefore, a substance is constituted by a principle of potency and a principle of activity, which, in the case of being human, are represented by body and soul.

The way in which Aristotle conceives of his understanding of substance takes into account two different issues, namely the relationship between universality and what is individual as well as the relationship between persistence and alteration (constancy and change) - both problems to which Plato responds in his own peculiar way. Hartman (1977:28-29) points out that Aristotle appears to believe that even Heraclitus holds that '... there is some sort of stuff that abides through all change', which is one of the conditions set by Aristotle for being a substance. On the next page, he adds that a substance, according to Aristotle, must be something, having form and belonging to a species, 'for only if it is such can it undergo certain changes and still remain what it is'.

In his above-mentioned recent penetrating work on the deconstruction of the principles of form and matter in the ontology and epistemology of Thomas Aquinas, Geert der Horst first explores the Greek background of the problem and within this context provides us with a brief summary statement of the successive responses to the problem of being and alteration (constancy and change). The issue is: How can we say that something is if experience teaches us that everything constantly changes? Ter Horst (2008) characterises the responses as follows:

The solution of Parmenides and to a lesser extent of Democritus is to reduce becoming to being. The solution of Heraclitus is to reduce being to becoming. Plato's solution is to maintain both becoming and being by assigning them to different domains. Finally, the solution of Aristotle is to attempt to maintain both by uniting them in a very peculiar way. (p. 68) ${ }^{4}$

In his extensive multi-volume work on Reformation and scholasticism in philosophy, Herman Dooyeweerd (2012a) distinguishes between theoretical designs (what Thomas Kuhn called paradigms), on the one hand, and the underlying ultimate commitments that give direction to theoretical views of reality, on the other hand. He designates the latter also as

3.For a more detailed discussion of Aristotle's notion of the Psuche as form, see Everson (1991:171ff.).

4.'De oplossing van Parmenides en in mindere mate van Democritus is om het worden te herleiden tot het zijn. De oplossing van Heraclitus is om het zijn te herleiden tot het worden. Plato's oplossing is om zowel het worden als het zijn te behouden door ze over verschillende domeinen te verdelen. Aristoteles' oplossing tenslotte poogt beide te behouden door ze op een heel bepaalde wijze met elkaar te verenigen.' 
religious ground motives. ${ }^{5}$ In this work, he provides a brief characterisation of the ancient Greek basic motive of form and matter, the biblical ground motive of creation, fall and redemption, the medieval (synthesis) motive of nature and grace and the modern humanistic ground motive of nature and freedom (see Dooyeweerd 2012a:1-20). ${ }^{6}$

\section{The medieval synthesis}

The attempted synthesis between the Greek ground motive and the biblical ground motive provides the basis for longstanding dualistic views of reality and the human person. The development of Greek philosophy does not reconcile the two ultimate, but opposing, principles of origin of matter and form. The only option is to assign primacy to one of the two poles. During the medieval era, the influence of the Greek motive of form and matter not only informed a dualistic understanding of reality but also a dualistic understanding of being human.

\section{Augustine}

According to Augustine, God did not create matter without form (Augustine 1982: Conf. 1.15). Later on, in his Confessiones (Augustine 1966:12 Conf. 6), when he explains that formless matter is formed concurrent with its creation, the crucial question remains unanswered: Is formless matter created? Whenever Augustine approaches matter in its absolute formlessness, it hides itself in utter darkness which can only be approximated by employing negative determinations (Augustine 1966:12 Conf. 6.6) similar to when it is defended that one can only say what God is not (a negative theological stance). In order to be faithful to the biblical creation motive, it is affirmed that matter is created, but not in its formlessness. The underlying tension reveals itself in the following dialectical formulation: By creating matter (which is distanced from God), God reaches the limits of its power (Augustine 1966:12 Conf. 7.7). This shows that the formless matter approximates the nihilo [nothing] of the idea of creatio ex nihilo [creation out of nothing], demonstrating that the 'nothing' after all is 'something (evil)'. Clearly, since matter is not created without form, the nihilo brings to expression the after-effect of the (depreciated) matter motive of Greek philosophy. The same legacy is found in Augustine (1966:12 Conf. 3), where the empty and desolate earth (Gn 1:2) is depicted as formless matter.

\section{Thomas Aquinas}

That Thomas Aquinas is dependent on both Aristotle and Neoplatonism explains why he characterises God as the

5.However, we should keep in mind that, within the Dutch language, it is possible to distinguish between the radical, central and integral meaning of religion, touching the heart of being human, and all the issues of life proceeding from this core dimension. Amongst these differentiated articulations, faith and confessiona activities are found alongside all the other issues of life (see $\operatorname{Pr} 4: 23$ ). In English, activities are found alongside all the other issues of life (see $\operatorname{Pr} 4: 23$ ). In English, the word religion is normally used only to designate the faith function of reality. Therefore, one should distinguish between religion in a functional (aspectual) sense touching the root of human existence, and integral means embracing all of life.)

6.The Aristotelian-Thomistic legacy is analysed in the second volume of Reformation and scholasticism in philosophy (see Dooyeweerd 2013a). primary form (prima forma exemplaris) of all things that participate in him. ${ }^{7}$ From this, Kremer (1971) concludes that:

$[\ldots]$ the ipsum esse per se subsistens becomes the arch-image of all forms and as such the original image of all beings. ... And if it is already the Form of forms, then every form derives from it, just as all beings do. Every being is then nothing but a limitation of this Form of forms, manifesting it in a bounded and limited way without limiting the Form of forms. ${ }^{8}$ (p. 316)

Aquinas struggles with the biblical revelation regarding creation, because he continues the Greek (PlatonicAristotelian) view on the first or primary matter (prima materia). An investigation of this issue shows that he solely relates substances constituted by form and matter to God's act of creation. As a result, Aquinas does not speak of primary matter in creational terms. In his Summa Theologica (Aquinas 1945: ST 1.44.2), in the third Objection, Aquinas argues that it is against the nature of matter, which exists only potentially, to be created. However, in his Reply, he responds by arguing that the Objection does not show that matter is uncreated but merely that it is not created without form. ${ }^{9}$ Aquinas (1945: ST 1.15.3) alleges that matter is created by God, but not without form. ${ }^{10}$ It is nonetheless repeatedly argued in his Summa contra Gentiles (S.c.G.) that God (as actus purus) brought everything into existence without prior matter. ${ }^{11}$ These statements do not solve the problem for the question is whether the formless primary matter was created in its formlessness? When Aquinas argues at the end of S.c.G. (19822.16) that, since God is the cause of all things (causa omnium), he is also the cause of primary matter (Deus igitur est causa materiae primae), he still does not provide a direct answer to this question. A consideration of the mentioned statements of Aquinas from Summa Theologica suggests that a direct answer in S.c.G. also should be that God did not create (first) matter without form. That is to say that God did not cause first matter without form. ${ }^{12}$ In itself, matter does not display being, and it is also not knowable. ${ }^{13}$

Matter continues to represent pure potentiality. According to Aristotle and Thomas Aquinas, form is the uniting factor within a substance. Yet, as Ter Horst (see 2008:53) points out, the fact that form cannot communicate, a true unity between being and matter is related to the abovementioned problematic view of Thomas Aquinas, namely that God cannot bring matter into being without form.

7.So for example in his commentary on Dionysius's De Divinis Nomibus, number 631

8.Kremer (1971) argues this point with extensive references from the works of Thomas. Compare also Kremer 1971:356-357 where he indicates that God according to Thomas, is (in a Neo-Platonic sense), the "utmost general/universal" [the 'Allerallgemeinste']. Kremer (1971:316) summarises it: 'Since whatever is outside God somehow has to participate in this Form, it [God] in fact becomes 'forma formarum' and 'Idee der Ideen' [the 'Idea of ideas'].

9.'Dicondum quod ratio illa non ostendit qoud materia non sit creata, sed qoud non sit creata sine forma.'

10.'Sed quia nos ponimus materiam creatam a Deo, non tamen sine forma.'

11.'Producit igitur Deus res in esse sine matria praciacente' (Aquinas 1982: S.c.G. 2.16).

12.Problems in Thomas's conception of creation are also extensively discussed by Sertillanges (1954:363-420) and Manser (1935:509-549).

13.Aquinas 1945: ST 1.15.3: 'Nam materia secundum se neque esse habet, neque cognoscibilis est.' 
The underlying dualism operative in all of this entails that only the compositum, the substance composed out of form and matter, comes into being and passes away for neither matter nor form as such is subject to coming into being and passing away. Ter Horst explains that, since primary matter is formless, no idea (form) of it can be conceived, implying that God does not have an idea according to which he could have created it. ${ }^{14}$ Alternatively Thomas Aquinas holds that potency is co-created (concreari) with what has been created primarily, namely substance (see Ter Horst 2008:74).

God does not contain anything potentially, and therefore, his essence coincides with his being. He is pure activity (actus purus), and therefore, being essentially applies to him who is 'ipsum esse per se subsistens' (see Aquinas 1945: ST 1.44.1c; 1982: S.c.G. 2.15.16).

\section{Complications for the anthropology of Thomas Aquinas}

Since Thomas accepts the view of Aristotle regarding the composite nature of the human being as substance, his view of the ontic unity and individuation of the composite substance (of body and soul) wrestles with serious problems. Combining act and potency (soul and body) entails a threat to the unity of being of the substance, because matter cannot be subsumed under the unity of form. Ter Horst (2008) explains the problem:

Matter in its potentiality has its own being independent of the form and with that independent of the substantial compositum. However, such an independent being of one of the principles of the substance inevitably abolishes the unity of the substance. The substance which is composed out of form and matter also does not have a true individuality, because flowing from its complete potentiality, matter without form cannot be a principle of individuality, whereas the form can communicate to matter only a generic being, not an individual being, and with that to the compositum. (p. 79) ${ }^{15}$

Plato, with his dualism between the intelligible world of static ontic forms and the sensory world of becoming (genesis), does not advance the view that the human being is composed of two substances, namely matter and form. Although he criticises Plato's view, Aristotle takes neither matter nor form to represent an independent substance. However, the subsequent medieval developments lead to the Thomistic struggle with the idea of a compositum, of a two-substance understanding of the human being. However, once body and soul are seen as substances, the question arises how the resulting substantial unity could be reconciled with two independent substances (body and soul)?

It should be kept in mind that the traditional scholastic view regarding the relationship between body and soul proceeds

14. He mentions Lib. LXXXIII, quaest. 46 where we read: 'sed materia prima nullam habet formam; ergo idea in Deo nulla ei respondet' (Ter Horst 2008:73).

15.'De materie bezit in haar potentialiteit een eigen zijn, onafhankelijk van de vorm, en daarmee onafhankelijk van het substantiele compositum. Een onafhankelijk zijn van a van een der substantiele beginselen heft echter onvermijdelijk de eenheid van de substantie op. De uit vorm en materie samengestelde substantie heeft ook geen ware individualiteit, daar de materie wegens haar volledige potentialiteit geen individuatiebeginsel kan zijn zonder de vorm, terwijl de vorm alleen een soortelijk zijn, geen individueel zijn, aan de materie, en daarmee aan het compositum, kan meedelen.' from the conviction that the soul is 'indestructible'.$^{16}$ This conviction has its foundation in the psycho-creationist conception. Whilst Thomas Aquinas accepts the active nous as being implanted from the outside, in addition, he has to take into consideration the church doctrine regarding the rational soul (anima rationalis) as a simple substance, accompanied by the psycho-creationist view according to which the soul must be created by God separately within the human body. Since the activity of the rational soul is independent of the body, the soul is viewed as existing by itself as a spiritual substance, which nonetheless is an incomplete substance.

Aquinas therefore struggles with the status of the human soul and its apparent borderline existence between bodily substances and separate substances. Natural things are substances 'composed out of matter and form' (Aquinas 1982:65, 281). Repeatedly Aquinas posits the problem: Can a spiritual substance (substantia intellectualis) be united with a body as its form? (see Aquinas 1982:289, 295, 403, 457).

The problem is how something subsistent could be a substance without ending up with a substance within another substance? The task formulated by Thomas Aquinas is to investigate how a spiritual substance could be united with a body? ${ }^{17}$ He aims at accounting for the way in which a spiritual substance (substantia intellectuali) and a body could essentially be united (become one) (Aquinas 1982:229, S.c.G. 56). Oftentimes the issue is stated in terms of the question whether a spiritual substance (substantia intellectuali) could be the form of a human body.

In the first article of his Questio disputata de anima, a distinction is made between a strict and a less strict manner in which something could be subsistent, and then he classifies the human soul as less persistent. Yet, ultimately the incorruptibility of the soul causes Aquinas to opt for the view that a human being '... is composed from a spiritual and corporeal substance'. ${ }^{18}$ Although the phrase substantia corporalis only occurs once in Aquinas' S.c.G., the conception is present throughout this work. In passing, we may note that, since Aquinas accepts the Aristotelian view (Aristotle 2001: Metaph. 1074a.34) that 'all things that are many in number have matter', there cannot be a multiplicity of form substances because they are supposed to be without matter.

According to Dooyeweerd (2013a:344), these tensions are the embodiment of the impossible attempt '... to achieve a synthesis between the Scriptural motive of creation and the Greek form-motive'. He here also points out that the Thomist view implicitly obtained its official ecclesiastical confirmation

16.In Chapter 55 of the first part of the Summa contra Gentiles, it is asserted that every intellectual substance is incorrruptible ('omnis substantia intellectualis est incorruptibilis'; see Aquinas 1982:215).

17.'restat investigandum utrum aliqua substantia intellectualis copori possit uniri' (Aquinas 1982:225, S.c.G. 56).

18.Aquinas 1945: ST 1.Q.75: 'De homine, qui ex spirituali et corporali substantia componitur.' 
at the Fifth Lateran Council chaired by Pope Leo X (c. 1513-1517), and he reminds us that the Aristotelian-Thomist doctrine of the soul as the substantial form of the body had already been adopted at the earlier Council of Vienne (1312) (Dooyeweerd 2013a:345).

In summarising the Greek legacy, it is clear that Aristotle transforms Plato's transcendent ontic forms into the (universal) substantial forms of material bodies without being able to escape from the ultimate dualism of matter and form as principles of origin, also reflected in the dualism between potency and act. He only considers the combination of form and matter as constitutive for the substantial unity of the human being. Although Plato already argued for the incorruptibility of the soul, Aristotle rejects the idea of the immorality of the soul - a feature attached only to the active reason (nous - which is not a soul) which operates from the 'outside' in order to become active within human thinking. Hence neither Plato nor Aristotle advances the idea that the human being is composed of two substances, body and soul. Within the developments of the medieval era, it was the church doctrine of the indestructibility of the human soul that resulted in the Thomistic view which accepted these two substances (body and soul).

Protestant theology continues the 'two substances' view by distinguishing between a (temporal) material body and an (eternal) rational soul (see Calvin n.d. Inst. 1.15.2; see also article 7 of the Swiss Confessio Helvetica Posterior and paragraph 2 of Chapter IV of the Westminster Confession).

\section{The dialectical root of modern philosophy}

Since the Renaissance, modern humanism has proceeded from the ideal to be free and autonomous. For this purpose, it has explored the possibilities of the modern natural sciences, supposedly capable of explaining reality entirely in terms of exact natural laws of cause and effect. In this way, a new dialectical basic motive has emerged, namely the motive of nature and freedom, also known as the natural science ideal and the personality ideal.

A dialectic similar to the Greek basic motive of matter and form and the medieval motive of nature and grace now gives direction to the development of modern philosophy. From the outset, an ultimate antinomy accompanied this development, for if everything is determined by the exact (physical) law of cause and effect, then human freedom also has to surrender to it. This is already seen in the thought of Descartes who commences by postulating two mutually irreducible substances, res extensa and res cogitans [the extended substance and the thinking substance]. It turns out that, in the final analysis, Descartes does accept an interaction between 'soul' and 'body', owing to the operation of a small gland, the parva glandula [the pineal gland]. This view paves the way for Spinoza, Hobbes and Leibniz to explore the primacy of the nature motive.
In the thought of Hobbes, for example, the human soul is reduced to a mechanism of feelings in motion. Rousseau (1975) starts to assign primacy to the freedom motive:

Nature commands every animal, and the brute obeys. The human being experiences the same impulse, but recognises the freedom to acquiesce or to resist; and particularly in the awareness of this freedom the spirituality of humankind manifests itself. (p. 47)

After his study of Galileo's Dialogues, Thomas Hobbes deepens his conviction that the only reality is that of motion. During his stay in the French capital, he entered into a polemic with Descartes concerning the latter's separation of soul in terms of mechanistic arguments. Ultimately the materialistic metaphysics of Hobbes subsumes the soul in all respects 'under the category of a moving body' (see Dooyeweerd 2012b:243-250).

This dominance of the nature motive (science ideal) is only curtailed by Immanuel Kant who transforms the distinction between essence and appearance (derived from the Greek concept of substance) into his own distinction between appearance and thing-in-itself, which is motivated by the nature-freedom (Sein-Sollen) dialectic: 'For if appearances are things in themselves, freedom cannot be saved' (Kant 1956:564). - He calls the human soul a 'thing-in-itself'.

The motivating influence of this dialectic in the basic motive of nature and freedom causes a negative understanding of freedom. It is always conceived as freedom from natural necessity. George Herbert Mead clearly understands how this motive has initially given rise to the dominant mechanistic tendency in modern physics since Galileo. In his The philosophy of the act, we read: 'The concept of nature which was introduced by Galileo through his doctrine of dynamics, reduced it to a statement of matter in motion' (Mead 1945:357). He realised that this doctrine has reduced reality to 'extended matter in motion' thus discarding the possibility of 'mind' because it denies the existence of so-called secondary qualities (such as colour, sound, warmth, taste, as well as the affective properties of things) (Mead 1945:358-359).

As a contemporary of Mead, Merleau-Ponty develops his own articulation of this basic dualism. He largely relies upon the results of psychological and psycho-pathological studies. Thus, the dialectic of nature and freedom assumes its own form in the thought of Merleau-Ponty. He explores two basic denominators, namely bodylines (in a biotical sense viewed as an organism) and existence (which for him is historical in nature). In following Sartre, he holds that, on the one hand 'I am my body' and on the other hand is he convinced that a person's historical existence must repress the bodily organism to the pre-personal level of an anonymous organic complex. ${ }^{19}$ The following two quotations respectively

19. Note the difference between the views of Merleau-Ponty and the meaning attached to the term organism in the thought of Aristotle. According to this meaning, every to the ters branch at once originates, exists and passes away with all the others, implying that

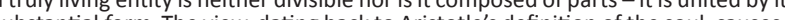
substantial form. The view, dating back to Aristote's definition of the soul, causes a misunderstanding of the word 'organikon' - see the discussion by Bos (2003:85ff., $93-94,107-108,162,174,200)$. 
represent the sentiments of the natural science ideal and the personality ideal (Merleau-Ponty 1970):

I cannot understand the function of the living body except by enacting it myself, and except in so far as I am a body which rises towards the world. (p. 75)

And:

... so it can be said that my organism, as a pre-personal cleaving to the general form of the world, as an anonymous and general existence, plays, beneath my personal life, the part of an inborn complex. (p. 84)

The dialectical situation is clear: On the one hand, I am my body, and on the other hand, my body is seen as a prereflexive, pre-personal, anonymous complex by virtue of its being-in-the-world (Merleau-Ponty 1970:79-80, 82-83, 86). Nature and freedom mutually threaten and presuppose each other (Merleau-Ponty 1970):

[...] for most of the time personal existence represses the organism without being able either to go beyond it or to renounce itself; without, in other words, being able either to reduce the organism to its existential self, or itself to the organism. (p. 84)

His thoughts jump dialectically to and from between these poles (Merleau-Ponty 1970):

Man taken as a concrete being is not a psyche joined to an organism, but the movement to and fro of existence which at one time allows itself to take corporeal form and at others moves towards personal acts, (my emphasis - DFMS). (p. 88)

Another prominent thinker of the early 20th century, Ludwig Wittgenstein, highlights another side of the nature-freedom split. In his Notebooks (Wittgenstein 1961), he holds that we are in a certain sense dependent and '... what we are dependent on we can call God.' To this he adds the statement: 'There are two godheads: the world and my independent I' $^{\prime}$ Wittgenstein 1961:74-75)..$^{20}$

The philosophical anthropology of Max Scheler, Adolf Portmann and Arnold Gehlen is guided by the primacy of the freedom motive. Modern (neo-)Darwinism in its genetic determinism (as advanced by Dawkins and others) assigns primacy to the nature motive. The Nobel-prize winner, Walter Gilbert (a biochemist from Harvard University), claims that the (Socratic) instruction 'know thyself' actually refers to (biological) knowledge of the human 'genome'.

An opposing view is advanced by Stephen Gould for he believes that 'the issue is not universal biology versus human uniqueness', but 'biological potentiality versus biological determinism' (Gould 1992:252). Potentiality here represents the humanistic freedom motive, and determinism represents the classical humanistic science ideal. Gould rejects the meaningless speculations of sociobiologists and alternatively posits human flexibility encompassing a vast range of potential behaviour. Ultimately Gould aims at maintaining a relative balance between these dialectically opposing poles of the basic motive of nature and freedom.

20.'Es gibt zwei Gottheiten: Die Welt und mein Unabhängiges Ich.'
Karl Jaspers realises the dead alley present in this dialectical legacy: 'Since freedom is only through and against nature, as freedom it must fail. Freedom is only when nature is' (Jaspers 1948:871).

\section{Towards an alternative view}

Although the main contours of the preceding analysis focused on the dialectics entailed in ultimate commitments, it was inevitable that alternative ontological stances came into view as well. However, what is particularly striking in all cases is that the ontological views involved all suffered from some or other form of reductionism. For example, in the position taken by Descartes, we find a reduction of nature to spatial extension and a reduction of what is typically human to thinking. By and large, the dualistic legacy regarding the relationship between body and soul operated with a split between the physical and a non-physical (mind or spirit).

It is clear that throughout this history, the human self-hood has been approached from the angle of various modes of explanation. The result is that, implicitly, the human self-hood became dispersed within the diversity of reality manifest in attempts to explain the mystery of being human merely in terms of one or another aspect of reality.

The history of philosophy and the various academic disciplines witness alternative options such as a material self, a genetic self, an emotional self, a rational self, a historical self, an interpretative self (homo symbolicus), an economic self (homo economicus) or a moral self. Sometimes a combination of aspects is employed such as the well-known characterisation of a human person as a rational-ethical being.

Increasing research on the human brain inspired reflections of the assumed relationship between the human 'mind' and the human brain. Within this field, strong reductionist tendencies surfaced, particularly by those who believe that it is the brain that thinks. Although no one will deny today that thought activities proceed on the basis of brain activities, it does not follow that we may assume that it is the brain that is thinking. Speaking and communicating are therefore not brain activities, as pointed out by Janich: ' $[I] \mathrm{t}$ is not brains that communicate, but interacting persons' (Janich 2009:73).

\section{Habermas rejects a naturalistic reductionism}

Habermas characterises (and rejects) the current naturalistic determinism, which pursues reductionist research strategies aiming at a complete explanation of mental processes by means of observable physiological conditions. According to this view, the freedom of the human will is therefore a mere appearance behind which a closed causal connection of neural states, determined by natural laws, hides itself. Yet, then he (Habermas 2005), asks the question:

But does the deterministic conception represent a thesis with a natural scientific foundation at all, or does it simply form part of a naturalistic world view resulting from a speculative interpretation of natural scientific knowledge? (p. 156) 
Elsewhere he asks whether the physiology of our consciousness changes anything of our intuitive awareness of being the accountable author guiding all our actions (Habermas 2001:16). His non-reductionist sentiments are evident in his remark (Habermas 2001):

The scientistic belief in a science which one day in the future not only will broaden our personal self-understanding, but through an objectifying self-description will also eliminate it, is not science but bad philosophy. (p. 20) ${ }^{21}$

\section{Implications of a biblical perspective}

From a biblical perspective, being human is not exhausted by any aspect or structure of temporal reality. The radical and central unity of being human transcends both the dimension of aspects and that of entities because it touches the root, the religious centre of a human person, sometimes designated as the heart, the soul or the spirit. We have shown that the traditional dualism of body and soul derives from the reification of opposing clusters of modal functions, as a rule by allocating the natural sides of reality to the (material) body and the norming modes to the (rational) soul.

According to Vollenhoven, the biblical sense of 'immortality' means '... not being subject to the power of death - in the Scriptural sense of this term'. Before the first death, human immortality is not mentioned, and the Bible never speaks of an immortal part of a person (it does not know the expressions 'immortal soul' and 'immortal spirit'). Moreover, the Bible solely knows of immortality of those who, after their death, are in Christ. Immortality means more than 'continue to exist' whilst 'being subject to death' does not mean annihilation (Vollenhoven 1933). The crucial biblical emphasis on the unity of the whole person (both in the Old and New Testament) is thoroughly discussed by Janse in his work Van Idolen en Schepselen (1938:50-86).

The dualism between 'matter' and 'spirit' denies the integral coherence of both the various aspects and the various kinds of entities found within the world. Dooyeweerd points out that the 'anima rationalis' is merely a theoretical abstraction from the temporal human body. Moreover, it 'contradicts the view that the "intellect" is its essence and that the "body" is its "matter"' for '... the intellect after all is within this conception not the entire soul' (Dooyeweerd 1939:203; see also 2013b:159). Dooyeweerd (1939) proceeds:

In the Aristotelian-Platonic theory of immortality this clearly comes to expression. Here immortality is only reserved for the nous - viewed as the intellect purified from all sensitive functions (the rational part of the soul in Plato). (p. 203)

The basic contours of an integral, biblically informed understanding of the human personality therefore requires an account of the coherence between the various modal aspects of reality, of the diverse subject-subject and

21.'Der szientistische Glaube an eine Wissenschaft, die eines Tages das personalen Selbstverständnis durch eine objektivierende Selbstbeschreibung nich nur ergänzt sondern ablöst, ist nicht Wissenschaft, sondern slechte Philosophie.' subject-object relationships found within them as well as of the complex intertwinement of different (sub-)structures within the human body.

Human beings function actively, that is as subjects, within all aspects of reality (see Figure 1)). Each human person is one, occupies space, moves, acts, is alive, is sensitive, identifies and distinguishes, is culturally formative, speaks, is thrifty, is beautiful (or ugly), can be just, loving and trusting (compare the aspects listed in Figure 1).

By contrast, material things only function actively within the aspects of number, space, the kinematic and the physical. In all the post-physical aspects, physical entities have object-functions: a diamond, for example, does not live, but nonetheless may be present within the habitat of living entities. A diamond is not a sensory subject, but it can be perceived by sensory subjects (animals and humans). A diamond cannot identify and distinguish, but human beings are capable to identify diamonds and distinguish them from whatever is not a diamond. Diamonds are not by nature cultural objects, but human beings can provide them with a cultural shape. They have no lingual ability but do have a name. Diamonds cannot interact socially but may be a status symbol. Surely they cannot be economically active although they may be pricey. Diamonds are beautiful, can be owned by someone (property right) and may be adored. Finally, once they have been given a particular cultural shape, they are reliable in performing a specific expected function.

The identification of the human body with what is considered to be material (physical) lacks a proper understanding of the fact that, within the human body, four different entity structures are intertwined in such a way that each retains its inner sphere of operation whilst at the same time contributing to the functioning of the entire human body. There is more to the atoms and molecules than what meets the eye! Consider for example the role of iodine within the normal functioning of the thyroid gland.

This gland (the glandula thyreoidea) is found around the lower part of the human larynx and the beginning of the wind pipe. It regulates the secretion of the thyroid gland hormone (thyroxine) which initiates the exchange of substances throughout the body's cells by influencing the process of oxidative phosphorylation in the mitochondria, an organelle within the cell. These processes are crucial for normal biotic growth as well as for emotional and psychic health. Yet, iodine has a physical-chemical qualification in respect of its own inner structure. Whilst maintaining this physical structure, it is nonetheless said to be enkaptically bound within the organic functioning of the thyroid gland.

Dooyeweerd introduces the term enkaptic to account for forms of interlacement or intertwinement where the inner sphere of operation of what is interlaced is not violated in spite of the fact that it simultaneously renders an external 


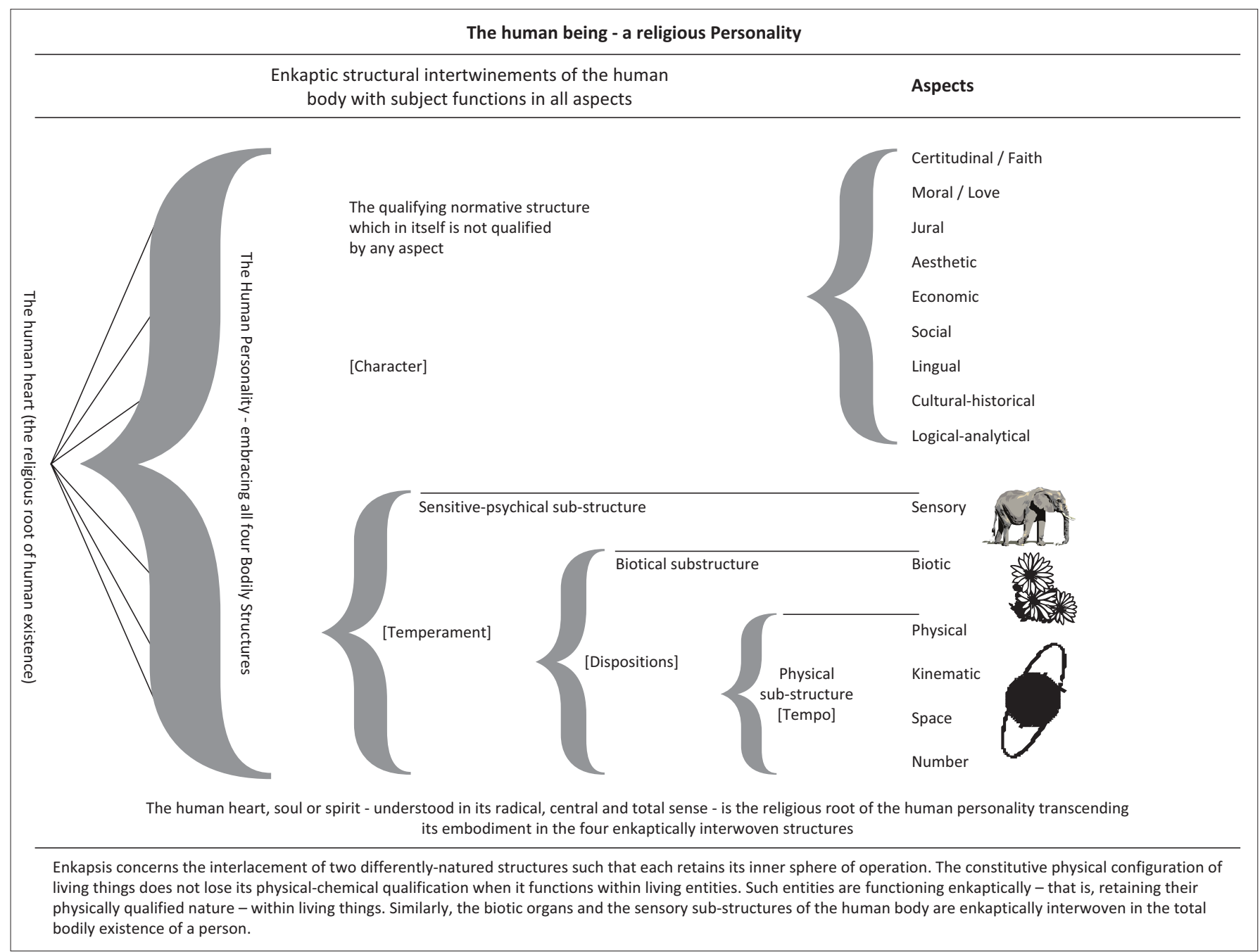

Source: Authors own work

FIGURE 1: The human being: A religious personality.

service to the whole of which it is an enkaptic part. Diverse natural and societal entities are designated by Dooyeweerd as individuality structures.

It is only the thyroid gland that actively (subjectively) functions within the biotic aspect of reality in dependence upon the enkaptically bound iodine responsible for the internal secretion of the thyroid gland hormone. This biotic function, in turn, plays a foundational enkaptical role within the sensitive sub-structure as well as within the normative functioning of the human being. It is important for the healthy emotional and norm-guided life of human beings. When the thyroid gland is hyperactive, it causes excessive energy use, which can generate a faster heartbeat accompanied by a general unease and a heightened nervous sensitivity. The interwoven iodine and thyroid gland therefore indeed operates within the integrated functioning of the entire human being without sacrificing its inner sphere of operation, which continues to be qualified by the physicalchemical and biotic aspects respectively.

Whilst all the bodily structures of humans have, apart from their enkaptic interweaving, a characteristic internal functional sphere, it is impossible to delimit any one of them in a morphological sense, that is, to localise them within any particular part of the body. This explains why the foot, the hand or the leg of a human being is never purely physically, biotically or sensorially structured. The entire human personality, embracing all enkaptically interwoven substructures, is expressed in every part of the body. Therefore, it is impossible for medical and nursing practice to reduce a person to a purely biotic entity.

Initially Dooyeweerd struggled to come to terms with what he eventually designated as the act structure of the human body. At a certain stage in the development of his thought, he opted for the idea that there is a 'spiritual' ('geestelijke') structure in which the pre-logical sub-structures are enkaptically bound but then added the remark that this spiritual structure is qualified by the faith function ('door de geloofsfunctie gequalificeerde ... lichaamsstructuur' Dooyeweerd 1940a:222).

However, since a human being can successively act under the guidance of diverse normative considerations, it is clear that none of the post-sensory (normative) functions could 
qualify these normed actions all at once. The result was that Dooyeweerd advanced the idea that, although the act structure is the qualifying structure of the human body, it is not qualified in itself (see Dooyeweerd 2011:165ff.). Another way to characterise this qualifying act structure is to say that it is undifferentiated (see Dooyeweerd 2011:175ff.). He (Dooyeweerd 2011) describes 'acts' as follows:

By the word 'acts' - differentiated in their basic dimensions of knowing, imagining and willing - I understand those activities which issue from the human selfhood but function within the enkaptic body individuality-structure. Through them, one orients oneself intentionally (i.e., with a purpose) towards states of affairs in temporal reality - or in the world of one's imagination - under the guidance of normative points of view. One internalizes these intentional (or intended) states of affairs by relating them to one's I-ness. Their 'innerness' is involved in the intentional character of the 'acts'. (p. 148)

Perhaps it would be simpler to avoid the distinction between 'inner' and 'outer' by simply calling this structure the normative structure. Interestingly, during the first few decades of the development of the Philosophy of the cosmonomic idea, both Dooyeweerd and Vollenhoven experimented with the idea of the functional garb of a human being (see Vollenhoven 2005:§93, p. 62; Dooyeweerd 1939:204; 2013b:160). Eventually Dooyeweerd employed his idea of individuality structures an approach not shared by Vollenhoven.

The non-reductionist ontology found in the philosophy of Dooyeweerd and Vollenhoven, on the one hand, acknowledges that the aspects within which human beings actively function are fitted within an unbreakable coherence in such a way that no single one should be elevated above all the others, as it is found in the distorting one-sidedness of well-known isms such as atomism, holism, physicalism, biologism, psychologism, logicism, historicism, aestheticism, legalism or moralism.

Elevating something within creation is normally accompanied by depreciating something else - the cause of dialectical oppositions which result in the confusion of the good structure of the creation order with the directional antithesis between good and evil (redemption and sin). This is also well-documented in the elevation of the human (intellectual) 'soul' (supposedly 'good') and the depreciation of the human (material) 'body' (supposedly inherently 'evil').

A radical biblical perspective rejects every dualism. From the depth perspective of the Christian worldview, we should realise that we are constantly confronted with the deification of something within creation. Absolutisations like these constantly distort a proper understanding of the human 'I-ness', because they rest on an over-evaluation of a wellcreated part of reality, which at once leads to a depreciation of something else within creation - already a fundamental characteristic of the ancient heresy of Gnosticism. This attitude idolises (deifies) something within creation - a point of departure of all idolatrous service, which glorifies creatures instead of God.
Before closing the analysis, however, I have to focus briefly on the discussions generated by the idea of supratemporality.

\section{Supra-temporality}

Vollenhoven and Dooyeweerd consistently subscribed to the distinction between the central (pre-functional or supra-modal) religious root (heart) of being human and the aspectual diversity within reality. However, Vollenhoven did not accept the idea of supra-temporality. Nonetheless, in his Isagôgè philosophiae, he does explain that time is not an aspect and also briefly accounts for the appearance of time within all modalities (see Vollenhoven 2005:§48, p. 33) - a view equivalent to what Dooyeweerd does (1940a; 1940b).

Vollenhoven (1968:3) mentioned that he was initially influenced by Poincaré who believed that the succession of numbers is connected to or founded in the succession of time. With reference to the succession of numbers and time, he (Vollenhoven 1968:3) notes that Dooyeweerd concludes from the temporality of reality that it must then include the arithmetical as well. Yet, Vollenhoven and Dooyeweerd share the distinction between the heart or soul and the functions (Vollenhoven's preferable mode of expression is to refer to the pre-functional heart in this regard). Of course, from a purely logical point of view, the acknowledgement of time embracing all aspects (and entities) by itself does not turn this distinction (between modal and supra-modal) into an impasse. An additional argument is required to show this.

In his response to the 'marginal' remarks, formulated by Van Peursen in respect of his A new critique of theoretical thought, Dooyeweerd revisited his initial assessment of the central religious dimension as something 'supra-temporal'. Dooyeweerd holds that we '... do transcend time in the center of our existence even though at the same time we are enclosed within time' (Dooyeweerd 1960:103). Later on in this article, he explains that he is not wedded to the term supra-temporal for, in response to the objection raised by Van Peursen to the term supra-temporal, he (Dooyeweerd 1960) says:

Now I am not once more going to enter into a discussion regarding the question if it is desirable to call the heart, as the religious centre of human existence, supra-temporal. It is sufficiently known that amongst the adherents of the Philosophy of the Cosmonomic Idea there is no consensus in this regard. Probably the term supra-temporal, with which I never meant a static condition but merely intended to capture a central direction of consciousness transcending cosmic time, can best be replaced by another one. (p. 137)

In 1964, the same issue surfaced in a discussion of the Annual Meeting of the philosophical association founded by Vollenhoven and Dooyeweerd. A transcription of this discussion reports that Steen asked Dooyeweerd about the idea of supra-temporality. Dooyeweerd answered that he could sometimes 'tear the hair from his head' that he ever used this expression. Nonetheless, he continued to hold that the human being, in the centre of its existence, transcends 
the temporal cosmic order. ${ }^{22}$ What is of importance for Dooyeweerd is the centrality of the human selfhood in the sense that it cannot be identified with any modal aspect or with any 'individuality structure' - and not the distinction between temporal meaning diversity and the 'supra-temporal heart' per se. Already in 1939, one finds formulations that emphasise that the supra-temporal is experienced ${ }^{23}$ in the deepest core of the human being. Dooyeweerd here also points out that the awareness of eternity resides in the human heart by virtue of its createdness. ${ }^{24}$

Throughout A new critique of theoretical thought (and elsewhere), Dooyeweerd merely refers to the central or transcendent religious dimension of creation without necessarily adding the qualification supra-temporal, In light of his 1960 and 1964 remarks, it is clear that the distinction between temporal and supra-temporal is not crucial for his philosophy. Just recall his remark that he '... never meant a static condition but merely intended to capture a central direction of consciousness transcending cosmic time' (Dooyeweerd 1960:137). What is therefore crucial is the distinction between God and creation as well as the centrality of the human selfhood (heart), coupled with the centrality of the core dimension of creation where the ultimate commitment of being human has its seat and from where direction is given to all of life. This does, however, not entail a dualism between body and soul in its traditional Aristotelian-Thomistic sense (see also Dooyeweerd 2012a:31-36). The distinction between the central religious dimension of creation and the dimensions of modal aspects and concretely existing (natural and social) entities ('individuality structures') remains valid irrespective of whether they are all seen as temporal or whether the central religious dimension is seen as 'time transcending' or 'supra-temporal'. After all, when Dooyeweerd (1960:137) speaks of a 'central direction of consciousness transcending cosmic time', it is clear that the central direction of the self-hood differs from the nature of the self-hood.

\section{Concluding remark}

An integral view of the human person, not succumbing to any dialectical or dualistic view, has to proceed from a non-reductionist ontology entailing the distinctiveness of structure and direction. The unity and goodness of creation indeed precludes a dualistic understanding of the origin of the universe in which certain parts are elevated and others depreciated. Wolters (1981) succinctly states:

22. The transcription reads: '... waar ik soms de haren uit mijn hoofd trek (you understand?), dat ik deze uitdrukking ooit zo gebruikt heb, ik geloof niet da ik deze uitdrukking ooit zo gebruikt heb. Ik heb wel dit gezegd, dat de mens in het centrum van zijn bestaan de tijdelijke, de kosmische tijdelijke orde te boven gaat. Dat is wel iets anders' (the Dooyeweerd Archives available at the 'Historische Documentatiecentrum,' Free University, Amsterdam - investigated during March, 2006).

23.Time only turns into a genuine problem 'wanneer wij distantie tegenover hem kunnen nemen in het boven-tijdelijke, dat wij in het diepst van ons wezen ervaren kunnen nemen in het boven-tijdelijke, dat wij in het diepst van ons wezen ervaren'
[... when we can take distance to it in the spura-temporal that we experience in the deepest core of our being] (Dooyeweerd 1939:1).

24.'De geheele Heilige Schrift leert ons immers, dat het eeuwigheidsbesef aan 's menschen hart is ingeschapen' (Dooyeweerd 1939:2, note 1).
In my view, it ought to be a mark of philosophy which seeks to be as radical as the Bible that it renounces this whole enterprise, and simply accepts, as a point of departure, that every creature of God is good, and that sin and salvation are matters of opposing religious direction, not of good and evil sectors of the created order. All aspects of created life and reality are in principle equally good, and all are in principle equally subject to perversion and renewal. (pp. 10-11)

\section{Acknowledgements Competing interests}

The author declares that he has no financial or personal relationship(s) that may have inappropriately influenced him in writing this article.

\section{References}

Aquinas, Th., 1945, Basic writings of Saint Thomas Aquinas, vol. 1 \& 2, ed. A.C. Pegis, Random House, New York.

Aquinas, Th., 1982, Summe gegen die Heiden, vol. 2, ed. \& transl. K. Albert \& P. Wissenschaftliche Buchgesellschaft, Engelhardt.

Aristotle, 2001 [1941], The basic works of Aristotle, ed. R. McKeon with an introduction by C.D.C. Reeve, The Modern Library, New York.

Augustine, A., 1966, Confessiones (Confessions), transl. \& introduction R.S. PineCoffin, Penguin Books, Harmondsworth.

Augustine, A., 1982, De Genesi ad litteram (The literal meaning of Genesis), transl. \& annotated J.H. Taylor, Newman cop, New York N.Y.

Bos, A.P., 2003, The soul and its instrumental body: A reinterpretation of Aristotle's philosophy of living nature, Brill, Leiden-Boston. http://dx.doi. org/10.1163/9789004247635

Calvin, J., n.d., Institutes of the Christian Religion, viewed from ///C:/Users/Danie/ Downloads/Confessio_Helvetica_posterior\%20(1).pdf

Dooyeweerd, H., 1939, 'Kuyper's Wetenschapsleer', Philosophia Reformata 4(4), 193-232.

Dooyeweerd, H., 1940a, 'The problem of time in the philosophy of the cosmonomic idea I', Philosophia Reformata 5(3), 160-192.

Dooyeweerd, H., 1940b, 'The problem of time in the philosophy of the cosmonomic idea II', Philosophia Reformata 5(4), 193-234.

Dooyeweerd, H., 1960, 'Van Peursen's critische vragen bij "A new critique of theoretical thought"', Philosophia Reformata 25(1/2), 97-150.

Dooyeweerd, H., 2011, Reformation and scholasticism in philosophy, vol. III, Philosophy of nature and philosophical anthropology, Paideia Press, Grand Rapids.

Dooyeweerd, H., 2012a, Reformation and scholasticism in philosophy, vol. I, The Greek prelude, Paideia Press, Grand Rapids.

Dooyeweerd, H., 2012b, The struggle for a Christian politics, Paideia Press, Grand Rapids.

Dooyeweerd, H., 2013a, Reformation and scholasticism in philosophy, vol, II, The philosophy of the cosmonomic idea and the scholastic tradition in Christian thought, Paideia Press, Grand Rapids.

Dooyeweerd, H., 2013b, 'Kuyper's philosophy of science', in S. Bishop \& J.H. Kok (eds.), On Kuyper: A collection of readings on the life, work \& legacy of Abraham Kuyper, pp. 153-178, Dordt College Press, Dordt.

Everson, S. (ed.), 1991, Psychology: Companions to ancient thought 2, Cambridge University Press, Cambridge.

Fischer, E.P., 1996, Aristoteles, Einstein \& co, Piper, München.

Gould, S.J., 1992, Reflections in natural history: Ever Since Darwin, WW Norton \& Company, New York.

Habermas, J., 2001, Glauben und Wissen, Suhrkamp, Frankfurt am Main.

Habermas, J., 2005, Zwischen Naturalismus und Religion, Suhrkamp, Frankfurt am Main.

Happ, H., 1971, Studien zum aristotelischen Materie-Begriff, Walter de Gruyter, Berlin. http://dx.doi.org/10.1515/9783110816747

Hartman, E., 1977, Substance, body, and soul, Princeton University Press, Princeton.

Janich, P., 2009, Kein neues Menschenbild: Zur Sprache der Hirnforschung, Suhrkamp, Frankfurt am Main.

Janse, A., 1938, Van Idolen en Schepselen, Kok, Kampen.

Jaspers, K., 1948, Philosophie, Springer Verlag, Berlin. http://dx.doi.org/10.1007/9783-642-49688-2

Kant, I., [1787] 1956, Kritik der reinen Vernunft, 2nd edn. (references to CPR B), Felix Meiner Edition, Hamburg.

Kremer, K., 1971, Die neuplatonische Seinsphilosophie und ihre Wirkung auf Thomas von Aquin, 2 nd edn., Brill, Leiden. 
Manser, G., 1935, Das Wesen des Thomismus, F. Rütschi, Freiburg.

Mead, G.H., 1945, The philosophy of the act, 2nd edn., Chicago University Press, Chicago.

Merleau-Ponty, M., 1970, Phenomenology of perception, transl. C. Smith, 5th edn., Routledge \& Kegan Paul, London.

Plato, 1966, The last days of Socrates, transl. H. Tredennick, Penguin Books, Hardmondsworth.

Rousseau, J.J., 1975, Du Contrat Social et Autres Oeuvres Politiques, Editions Garnie Fréres, Paris.

Sertillanges, A.D., 1954, Der Heilige Thomas von Aquin, transl. R. Grosche, 2nd edn., Hegner, Köln.

Swiss Confessio Helvetica posterior, file:///C:/Users/Danie/Downloads/Confessio_ Helvetica_posterior\%20(1).pdf

Ter Horst, G.J., 2008, De ontbinding van de substantie: Een deconstructie van de beginselen van vorm en materie in de ontology en de kenleer van Thomas van Aquino, Uitgeverij Eburon, Delft.

Thompson, M., 2012, Understand philosophy of mind, Hodder Education, London.
Verdenius, W.J. \& Waszink, J.H., 1968, Aristotle on coming to be and passing away, E.J. Brill, Leiden.

Vollenhoven, D.H., 1933, Het Calvinisme en de Reformatie van de Wijsbegeerte, H.J. Paris, Amsterdam.

Vollenhoven, D.H., 1968, 'Problemen van de tijd in onze kring', presentation to the Circle of Amsterdam (Association for Reformational Philosophy - Chairperson Dooyeweerd). Text based upon a tape recording by J. Kraay, checked and corrected in a few instances by Vollenhoven, with a six point summary written by Vollenhoven himself (added on page 8), available as Stenciled Hand-out.

Vollenhoven, D.H., 2005, Isagôgè philosphiae: Introduction to philosophy, ed. J. Kok \& A. Tol, Dordt College Press, Dordt.

Westminster Confession, http://uk.wow.com/search?s_pt=aolsem\&s_it=aolsem\&s_ chn=47\&q=westminster\%20confession $\% 20$ pdf.

Wittgenstein, L., 1961, Notebooks 1914-1916, ed. G.H. von Wright \& G.E.M. Anscombe, transl. G.E.M. Anscombe, Basil Blackwell, Oxford.

Wolters, A., 1981, 'Facing the perplexing history of philosophy', Journal for Christian Scholarship 17(4), 1-31. 